\title{
TRADING STAMPS AND LEGISLATION PERTAINING THERETO
}

Aaron Shtabsky, B.Comm., Third Year Law, University of Alberta

Although trading stamps were in common use in the Canadian economic sphere well before the turn of the century, no attempt was made by the Parliament to introduce legislation governing their use. However, in 1905 the federal government felt that legislation was necessary to curtail the use of trading stamps and the practices being employed by the trading stamp companies.

It was a common practice at that time for a trading stamp company to be formed to sell trading stamps to various retailers. These retailers would then issue the stamps, which were redeemable by the trading stamp company, to their customers. In many instances, the companies would disappear before these customers had an opportunity to redeem their stamps.

The 1905 federal legislation was incorporated into the Criminal Code. It required that trading stamps be redeemable upon demand by the issuing merchant. In R.v. Western Automobile Club Limited' the Supreme Court of Alberta, Appellate Division, held that the 1905 legislation was intra vires. Clarke, J.A. at page 432, stataed:

I find that it (the 1905 legislation) has been in the statute (the Criminal Code) for many years and its validity has never been questioned by any Court so far as I am aware. It appears to me to come within the domain of Criminal Law allotted to the Dominion Parliament by the B.N.A. Act, 1867.

Thus ,it is evident that as early as 1905 trading stamps were a problem of federal stature. The 1905 enactment was an attempt to deal with this problem. It attempted to curtail the general use of trading stamps, and in particular, to combat the fraudulent practices of trading stamp companies. The 1905 legislation, as incorporated into the Criminal Code, has since stood as the foundation of federal trading stamp legislation in Canada, modified by a minor amer.dment in 1906 and a general revision in 1953.

The 1905 legislation appeared as sections 526A and 526B of the Criminal Code. Section 526A outlined what constituted the of fence and 526B set out the penalty for infractions of 526A. Within these sections, Parliament included a definition of trading stamps so as to indicate the abuse at which the legislation was directed.

In 1906 this definition, with its wording practically unchanged, appeared as section 335, and the penalty section was rewritten and appeared as sections 505 and 506. The 1927 revision of the Criminal Code resulted in some very slight changes in the wording and numbering of the sections, but, there was no change whatever in the law pertaining to trading stamps. However, a general revision of the Criminal Code appeared in 1953, resulting in amendments of considerable importance with regard to trading stamps. Schultz, J.A. summarized the effect of the 1953 revision in $R$. v. Loblan Groceterias Co. (Manitoba) Limited:" 
1. Prior to 1953 the penalty section made the issuing or giving of trading stamps indictable offences, but subsequent to the amendments such acts were made summary offences only.

2. Prior to 1953 the purchaser of goods who received or took trading stamps from the vendor of such goods was liable on summary conviction to a fine not exceeding $\$ 20$, but in the amendment of 1953 , this provision was eliminated.

This second provision is an indication of how, in 1953, Parliament looked upon trading stamps in a different light to that in which it first considered them in 1905. Schultz, J.A. in another 1960 case stated: ". . . I think it is a fair inference that Parliament no longer considered the receiving or taking of trading stamps by a purchaser of goods an offence."

3. From 1905 until the introduction of the 1953 amendment, the definition section read in part:

.. . trading stamps includes, besides trading stamps commonly so called, any form of cash receipt, recejpt coupon, premium ticket or other device designed or intended to be given to the purchaser of the goods by the vendor.

The amendment of 1953 deleted the underlined words and this deletion has resulted in much controversy over what interpretation Parliament intended to place on the words "trading stamps."

Today, the provisions relating to trading stamps appear in the Criminal Code as sections 322 and 369 , and read as follows:

\section{PART VIII-Fraudulent Transactions Relating to Contracts and Trade}

Interpretation.

322 ()b. 'trading stamps' includes any form of cash receipt, receipt, coupon, premium ticket or other device, designed on intended to be given to the purchaser of goods by the vendor thereof or on his behalf, and to represent a discount on the price of the goods or a premium to the purchaser thereof

(i) that may be redemmed

(A) by any parson other than the vendor, the person from whom the vendor purchased the goods, or the manufacturer of the goods,

(B) by the vendor, the person from whom the vendor purchased the goods, or the manufacturer of the goods in cash or in goods that are not his property in whole or in part, or

(C) by the vendor elsewhere than in the premises where the goods are purchased; or

(ii) that does not show upon its face the place where it is delivered and the merchantable value thereof; or

(iii) that may not be redeemed upon demand at any time, but an offer, endorsed by the manufacturer upon a wrapper or container in which goods are sold, or a premium or reward for the return of that wrapper or container to the manufacturer is not a trading stamp.

TRADING STAMPS.

Issuing Trading Stamps-Giving to Purchasers of Goods.

369. (1) Every one who, by himself or his employee or agent, directly or indirectly issues, gives, sells or otherwise disposes of, or offers to issue, give, sell or otherwise dispose of trading stamps to a merchant or dealer in goods for use in his business is guilty of an offence punishable on summary conviction.

(2) Every one who, being a merchant or dealer in goods, by himself or his employee or agent, directly or indirectly gives or in any way disposcs of, or. offers to give or in any way dispose of, trading stamps to a person who purchases goods from him is guilty of an of fence punishable on summary conviction ....

From 1905 to 1956 federal legislation apparently was adequate to curb undesirable schemes involving trading stamps. However, a revival of the use

${ }^{3 R}$ egina Ex Rel Hryerk v. Loblaw Groceterias Co. (Manitoba) Limited, (1960) 31 W.W.R. 49 at p. 61 . 
of trading stamps occurred in 1956, bringing with it a fresh series of problems. Since 1956 all infractions of trading stamp regulations involved schemes which were very similar to one another. As a result of judicial rulings these schemes were modified so as to be within the law and so as to satisfy the courts' interpretation of the provisions in the Criminal Code.

Recent decisions based on infractions with regard to trading stamps, make it apparent that trading stamps may be classified in two ways: those which are illegal and constitute an offence under the Criminal Code; and those which are legal and cannot be subjected to the penalty as provided under section 369 . In order that a trading stamp not be subjected to the pinalty as provided in section 369 , the following requirements must be satisfied:

1. The stamps must be redeemed by the vendor.

2. The stamps must be redeemed in goods which are his property.

3. The stamps must be redeemed on the premises where the goods were purchased.

4. Each stamp must show legibly on its face the address of the store where it is redeemable and the merchantable value of the stamp.

5. The stamp must be redeemed upon demand at any time, no matter how small the number of stamps presented for redemption.

The above criteria setting out the present requirements for legal trading stamps have been largely enunciated as a result of litigation which followed the 1956 resurgence in the use of trading stamps. This evolution is best illustrated by an examination of recent cases. Shaw

Keirstead, Co. Ct. J. stated in United Promotion Sales Incorporated v.

... on the face of the stamps there is a statement 'merchantable value 1 mill.' I doube if that means much to an ordinary individual. It is certainly nos a statement of value in the ordinary usage. The stamp does not show on its face 'the place where it is delivered.' ...

After examining the stamps in evidence and considering the provisions of the $\dot{C}_{\text {Ciminal }}$ Code

I find the stamps before me fall within the definition set forth in Section 322 of the Code.

As a result of this decision a trading stamp must explicitly state its value and place where it is redeemable. Regina v. Rice and Fletcher," a decision from an Ontario Court made it clear that use of the word "London" was not sufficient to satisfy the requirement that the stamp must show "upon its face the place where it is delivered."

As a result of Regina v. Loblaw Groceterias Co. (Manitoba) Limited, (1959) an unreported decision of the Magistrates' Court of Manitoba, provisions were made for trading stamps being issued by the company to be immediately redeemable upon demand so as not to fall within Section 322 (b) of the Code. Previous to the conviction in this case, trading stamps were not immediately redeemable and a certain number of stamps were necessary before they could be redeemed. The question of immediate redemption was raised again and decided by the Manitoba Court of Appeal in Regina Ex Rel Hrycyk v. Lablaw Groceterias Co. (Manitobta) Limited." Schultz, J.A. felt that Parliament intended that redeemability of coupons and other devices was dependent on a demand or request being made by the purchaser or customer

4 (1957) 9 D.L.R. (2d) 759.

5(1959-60) 2 Criminal Law Quarterly 236.

"ref. 3, p. 64 . 
and was not, as Counsel for the Crown contended, "to avoid Section 322 (b) (iii), each stamp must have the characteristic of immediate and indefinitely continuing redeemability." He goes on to state that he interprets the trading stamp legislation to read that a reasonable time should be allowed to meet every demand for premiums and that there is no specific stipulation in the Code to the effect that every premium must be on hand. Failure to redeem trading stamps on demand was the basis on which the District Court Judge in Regina v. Loblaw Groceterias Co. (Sask.) Limited' convicted the accused of offending Section 322 (b) of the Criminal Code and therefore subject to the penalties outlined in Section 369.

The Manitoba Court of Appeal has held that if trading stamps issued are not trading stamps within the meaning of Section 322 (b) then no offence is committed, and the issuer cannot be prosecuted under Section 369 of the Criminal Code.

A Saskatchewan District Court's finding, in Regina v. O.K. Economy Stores Ltd.," that the accused was guilty of an offence contrary to Section 369 , was upheld on appeal ${ }^{10}$ on the basis that the stamps were not redeemable upon demand. However, it was pointed out in the Saskatchewan Court of Appeal by Culliton, J.A. that it is not essential that the exchange of the stamps and the premium must be contemporaneous in order for the transaction to be legal and not in contravention of the provisions in the Criminal Code.

To this point I have avoided all reference to the important problem of whether or not Section 322 (b), the definition section, intended to bring all trading stamps per se within the definition and to expand upon the ordinary meaning of the words; or whether Parliament intended to make Section 322 (b) exhaustive, in that only those trading stamps which are explicity referred to in the definition are illegal. Much litigation has resulted from the definition question, culminating in a recent appeal to the Supreme Court of Canada."

The stand taken by the Crown in Regina Ex Rel Hrycyk v. Loblaw Groceterias Co. (Manitoba) Limited ${ }^{12}$ points out one side of the issues. The Crown contended that Section 369 made trading stamps illegal without the need of referring to Section 322 to determine the meaning. The Crown said reference need only be made to the ordinary meaning of trading stamps and the Court was referred to the definition as found in Webster's Dictionary. Schultz, J.A. stated:

... if the wording of the statute, what is now Section 322 (b), had remained unaltered by the amendments of 1953.54 this argument (of the Crown's) would be conclusive, for the intention of Parliament would have been apparent and in accordance with what Counsel daims. But Parliament by amending the section deleted the very words that gave it the meaning which counsel contends.

The definition section, before being amended, read as follows:

trading stamps includes, besides trading stamps commonly so called, any form of cash recipt, receipt, coupon, premium ticket or other device, designed or intended to be given to the purchaser of the goods by the vendor.

The 1953 amendment deleted the underlined words and Schultz, J.A. con-

?(1960) 31 W.W.R. 280.

RRegina v. Loblaw Groceterias Co. (Manitoba) Limited (1960) 31 W.W.R. 433.

O(1959) 30 W.W.R. 529.

$10(1960) 31$ W.W.R. 481.

${ }_{11}$ The Queen v. Loblaw Groceterias Co. Led., and The Queen v. David Thompson Niagara Grocery (1961) 26 D.L.R. (2d) 485.

$12(1960) 31$ W.W.R. 40. 
cluded that the amendment limited and restricted the application of the term "trading stamps."

Tritschler, J.A. disagreed with Schultz, J.A. on the point as to whether Section 322 (b), as amended, abrogates the ordinary import of the term "trad. ing stamps." He felt it did not. He based his argument on the following reasoning: Section 322 (b) reads "trading stamps includes ..." and not "trading stamps means ...." or "trading stamps means or includes ...." He therefore concludes that trading stamps are only partially defined in Section 322 (b) and that all the Section does is to extend the ordinary meaning of "trading stamps." Tritschler, J.A. stated:

It is difficult to believe that Parliament intended subsection 322 (b) to be an all inclusive definition of 'trading stamps' because the word 'stamps' does not appear following the term 'includes'. The commonest offending object is not even mentioned. I think the words stamps would not have been omitted if it had not been considered that trading stamps, in the common meaning of he words, were still struck at by Section 369 and that Subsection 322 (b) was concerned with adding certain items to the prohibition against 'trading stamps' and not with defining the characteristics of trading stamps .... it is expansive and not restrictive. ${ }^{13}$

Regina v. Loblaw Groceteria Co. (Sask.) Limited No. $2^{11}$ follows the majority position taken by Schultz, J.A. in the Hrycyk case." The definition of trading stamps as found in Section 322 (b) was held to be exhaustive and that the word "includes" is to be construed as "means and includes." By this point, the courts were making it clear that only those trading stamps explicitly referred to by Section 322 (b) of the Criminal Code were prohibited under Section 369.

The case of Regina v. Loblaw Groceterias Co. (Manitoba) Limited "ave Schultz, J.A. a further opportunity to discuss the definition of trading stamps as found in the Criminal Code. He confirmed his earlier stand and expanded upon it, concluding that the word "includes" as used in Section 322 (b) means "means and includes" and that the definition therein is exhaustive. Freedman, J.A. supported Schultz, J.A., and he felt that a very unfair and discriminatory interpretation of the statute could result if the Courts were to hold that trading stamps per se were illegal. He compared the situation where you have a premium and where you have a trading stamp, both redeemable in exactly the same manner and both satisfying all the requirements of Section 322 (b). If the Crown's contention was found to be correct, that trading stamps per se were illegal, then the store issuing the premium would not be convicted. However, the store which has the identical premium, but in the form of a trad. ing stamp, would be prosecuted under Section 369 of the Criminal Code.

The Saskatchewan Court of Appeal in Regina v. O.K. Economy Stores Ltd. ${ }^{17}$ held that the word "includes" must be interpreted as "means and includes" and thus Section 322 (b) affords an exhaustive definition of trading stamps. This case is in full agreement with the decision of the Manitoba Court of Appeal.

In October, 1960, the Supreme Court of Canada consisting of Kerwin, C.J., Locke, J., Fauteaux, J., Abbott, J. and Maitland, J., heard an appeal from the Manitoba Court of Appeal decision in Regina v. Loblaw Groceteria

\footnotetext{
${ }^{13}$ Regina Ex Rel Hrycyk v. Loblan Groceterias Co. (Manitoba) Limiled (1960) 31 W.W.R. 49 at 5.72 .

14(1960) 31 W.W.R. 283.

15Regina Ex Rel Hrycyk v. Loblaw Groceterias Co. (Maniloba) Led. (1960) 31 W.W.R. 481.

10(1960) 31 W.W.R. 433.

17 (1960) 31 W.W.R. 481.
} 
Co. (Manitoba) Limited." In conjunction with this appeal the Court also considered the identical situation as it arose in Regina v. David Thompson Niagara Grocery." In a unanimous decision the Supreme Court dismissed the appeal, thereby upholding the position taken by Schultz, J.A. in the Manitoba Court. ${ }^{20}$

We can now safely conclude that Section 322 (b) provides an exhaustive definition of trading stamps. Only those trading stamps found thereunder will invite prosecution under Section 369 of the Code. It is possible therefore, for trading stamps to be legal, within the meaning of the Criminal Code, so long as the requirements set out in Section 322 (b) of the Criminal Code are met.

\section{ATTEMPTED PROVINCIAL LEGISLATION RE TRADING STAMPS}

Provincial legislatures attempted to control the use of trading stamps prior to 1905 , when Parliament passed its first trading stamp legislation. One of the first cases which challenged the validity of a provincial enactment dealing with trading stamps was Montreal Trading Stamp Co. v. City of Halifax." The legislature of Nova Scotia had amended the charter of the City of Halifax to read that:

... no person . shall give, sell or dispose of trading stamps, tickets or cards to any
person . . doing business in the City of Halifax, nor shall such persons so doing business
in the City. . t take or have in his possession any such trading stamps . . . nor shall any
vendor give, sell or dispose of any such trading stamps . . to any of his customers whereby
such customers shall be entitled to receive for such trading stamps... any money, personal
property...22

Graham, E.J. stated: ". . . it was contended that the Act was ultra vires the provincial legislature. In my opinion, it comes within the head of property and civil rights... or matters of a merely local or private nature in the province and is not a criminal law."

Both Ontario ${ }^{23}$ and Quebec ${ }^{24}$ enacted legislation dealing with trading stamps. The Ontario legislation was challenged in the Ontario Court of Appeal. ${ }^{2 \pi}$ There, the court held the provincial legislation valid as being a matter relating to civil rights in the province and not relating to trade and commerce, a federal matter. The Quebec courts held its provincial legislature's enactment to be ultra vires in Wilder v. City De Montreal."

Of the provincial legislatures, Alberta's has taken the boldest steps toward abolition of the use of trading stamps. Alberta's first legislation appeared in November of 1959. The minister of industry and development amended Alberta Regulation 239/57 under "The Licensing of Trades and Business Act" by issuing Alberta regulation 379/59. Section 15 of this regulation reads:

18 (1960) 31 W. W. R. 433.

10This Manitoba case went through the Courts along with Regina v. Loblaw Groceteria Co. (Manitoba) Limited (1960) 31 W.W.R. 433.

20This decision was handed down on December 19, 1960. The full report of the decision was not available when this article was being compiled. It can be found in (1961) 26 D.L.R. (2d) 485.

21 (1900) 36 Can. L.J. 468.

32Nova Soctia Act, 1899 Statutes Nova Scctia, Chapter 27, Section 2.

"Ontario Act, Municipal Amendments Act 1901 Stat, Ont., Chapter 26, Section 26.

24 Quebec Act, Chapter 39.

25This decision is unreported, but reference is made to it in Wilder v. Cite De Quebec (1905) 25 Que. S.C. 128 at 137.

2is $\{1905\} 26$ Jue. S.C. 504, 1905 XXV Canadian Law Times 91. 
15. No business licensed under The Licensing of Trades and Business Act shall secretly or otherwise give or offer to give any premium free good, or use coupons, ccupon books, stamps, trading stamps or similar plans for the purpose of furthering the sale of any commodity or service.

It was the aim of this regulation to completely abolish the use of trading stamps within Alberta. The first charge laid under the amended regulation was brought against one Joseph Kellet on August 24, 1960. He was charged with unlawfully using stamps for the purpose of furthering the sale of groceries, contrary to Section 15 of Alberta Regulation 239/57 amended by Alberta Regulation 379/59. Magistrate Barclay, on December 17, 1960, held the provincial regulations to be inoperative. ${ }^{27}$

In support of its argument the Attorney General's Department of Alberta submitted that legislation of this type might well be considered as within Section 92 (13) of the British North America Act, property and civil rights. Even though Parliament has seen fit to legislate upon trading stamps under the Criminal Code, the Attorney General's Department contended that the "double aspect" theory as stated in Hodge v. The Qucen"* was applicable. It was argued that a trading stamp offence per se was not a criminal of fence such as theft, and only because Parliament has legislated with regard to trading stamps has it become criminal. On that basis it cannot be said that the province is trying to encroach upon the criminal jurisdiction of Parliament as trading stamps are not in pith and substance criminal law. The Attorney General's Department further submitted that the field is not fully occupied by federal legislation, and so long as there is no conflict even if overlapping results, the federal legislation will not render the provincial legislation inoperative.

Counsel for the accused, Keller, submitted that sections 322 (b) and 369 provide an exhaustive system for the regulation of trading stamps. This contention was based on the court finding, as found in the Manitoba and Saskatchewan courts, that section 322 (b) provides an exhaustive definition of trading stamps. Counsel argued that if the court was to find that sections 322 (b) and 369 constituted an exhaustive system for the regulation of trading stamps, then the field was "fully occupied" and it would not be possible for the doctrine of "double aspect" to come into play as the provincial enactments would be held to be inoperative. Where both Parliament and a legislature have acted in a common area with the result that either there is a clash or conflict between the two enactments or the federal enactment so occupies the field so as to leave no room for the operation of the Provincial measure, the provincial enactment is overborne.

Magistrate Barclay in holding the Alberta regulation inoperative, felt provincial trading stamp legislation was in a "double aspect" area with an occupied field. He stated had Parliament not legislated with regard to trading stamps it would be a matter of property and civil rights or a matter purely local in nature and therefore within the jurisdiction of the provincial legislature. He went on to state that in his opinion the decisions in Manitoba and Saskatchewan dealing with trading stamps seems to indicate that the Criminal Code provisions do not exhaustively occupy the field, however, the definition

27The report containing this decision had not been received at the date of this article.

28 (1883) 9 A.C. 117.

20 Citizens Insurance Co. v. Parsons (1881) 7 A.C. 91. 
of trading stamps in the Code is exhaustive. Therefore, if the province legislated with regard to trading stamps so as to occupy the unoccupied portion of the field, it would be valid provincial legislation and operative. However, in his opinion the Criminal Code and the Alberta regulation were in pith and substance covering and dealing with the same subject matter, and on that basis the Alberta regulation is inoperative. As a second ground for holding the regulation as inoperative in the Keller case, Magistrate Barclay found that the minister had acted withont the proper delegation of power to pass the regulation in question.

The second ground for holding the regulation inoperative could be easily overcome by the Alberta legislature enacting a special act to deal with trading stamps. However, the first basis of the Keller decision is much more difficult to overcome. This is expecially true since the Supreme Court of Canada's decision in Regina v. Loblaw Groceteria Co. (Manitoba) Limited, ${ }^{30}$ to the effect that section 322 (b) of the Criminal Code provides an exhaustive definition of trading stamps.

The Alberta legislature was quick to react to the ruling of Magistrate Barclay in the Keller case. Alberta Regulation 406/60 was passed by an Order In Council and appeared in the Alberta Gazette of January 14, 1961. The Order In Council established a "General Code of Fair Competition and Business Practices." Section 3 reads:

3. No lieensee shall give or offer to give, directly or indirectly, any gife, premium, services, concession, prize or other bencfic of any kind or character whatsoever to any person

(a) who purchases any goods or service from the licensee, or

(b) to induce any person to purchase any goods or service from the licensee, or

(c) for the purpose of furthering the sale of any goods or service by the licensec.

The Order In Council is a clear attempt to completely abolish the use of trading stamps in Alberta. The wording is such that no reference whatever is made to the term "trading stamps" or "stamps". This indicates the province's intention to avoid encroaching upon the portion of the legislative field now occupied by Parliament, by virture of the Criminal Code.

The validity of this enactment will soon be tested as an Edmonton grocer has recently issued trading stamps. It will be of interest to see whether the province has succeeded in its aim of abolishing the use of trading stamps in Alberta.

In conclusion, as a result of recent decisions relating to trading stamps, such stamps can now be legally used in any province of Canada providing they do not contravene sections 322 (b) and 369 of the Criminal Code. Provincial legislatures can legislate within the field of trading stamps. However, provinces must be careful to enact legislation which does not encroach upon the jurisdiction of Parliament.

In Alberta, the provincial government has enacted legislation which attempts to make the use of trading stamps totally illegal. Whether this legislation is valid remains to be seen.

Following the results of recent cases, and pressure exerted by consumer groups and the provinces, it appears that the federal government is now contemplating a reconsideration of its stand with regard to trading stamps. In December of 1960, federal minister of Justice Davie Fulton said Parliament will "reconsider" the trading stamp problem.

${ }^{30}$ ref. 11. 